\title{
Lignite-based Organic Fertilizer Improves Soil Quality and Yield of Rice in Belitang South Sumatera
}

\author{
Syafrullah \\ Faculty of Agriculture, Muhammadiyah University Palembang \\ Jalan Jenderal Ahmad Yani, 13 Ulu Palembang 30263,*e-mail : syafrullahagro@yahoo.com
}

Received April 1, 2019; Revised August 25, 2019; Accepted 12 September 2019

\begin{abstract}
To achieve food-self sufficiency in Indonesia, it is necessary to apply sustainable agriculture practices to improve soil quality. Most of paddy fields have been applied with chemical fertilizers intensively for more than 40 years without the addition of organic matter. The purpose of this study was to understand the effects of lignite-based organic fertilizer application on the quality of paddy soil and yield of rice. The study was conducted in April until August 2014 in the irrigated rice fields in Belitang, Ogan Komering Ulu Timur District. The study was arranged in a Factorial Randomized Block Design, with 9 treatment combinations and 3 replicates. The first factor was the types of fertilizers, consisting of recommended chemical fertilizers $(250 \mathrm{~kg}$ urea $\mathrm{ha}^{-1}+150 \mathrm{~kg} \mathrm{SP} 6 \mathrm{ha}^{-1}+50 \mathrm{~kg} \mathrm{KCl} \mathrm{ha} \mathrm{k}^{-1}$ ), organic fertilizer from plant residue at $5 \mathrm{Mg} \mathrm{ha}^{-1}$, and lignite-based organic fertilizer (namely Baranik fertilizer) at $0.75 \mathrm{Mg} \mathrm{ha}^{-1}$. The second factor was rice varieties, consisting of Mentik Wangi, Gogo Aromatik and Ciliwung. The application of Baranik fertilizer at $0.75 \mathrm{Mg} \mathrm{ha}^{-1}$ has improved the quality of paddy soil with the increase of organic-C content from $1.44 \%$ to $2.90 \%$. Application of Baranik fertilizer at $0.75 \mathrm{Mg} \mathrm{ha}^{-1}$ has increased the vegetative components and the yield of rice about $7.17 \mathrm{Mg}$ $\mathrm{ha}^{-1}$ compared to the organic fertilizer from plant residue, but the yield is still the same as that in the recomended dosages of chemical fertilizers. Among the rice varieties, the yield of Ciliwung variety was higher than other varieties, i.e. $7.62 \mathrm{Mg} \mathrm{ha}^{-1}$. The yield of Gogo Aromatik variety is significantly lower than that of Ciliwung variety. Baranik organic fertilizer can be used to improve soil fertility for food security purpose.
\end{abstract}

Keywords: Food-self sufficiency, organic matter, rice, sustainable agriculture

\begin{abstract}
ABSTRAK
Untuk tercapainya Swasembada Pangan di Indonesia, perlu adanya penerapan pertanian berkelanjutan guna meningkatkan kualitas tanah. Rendahnya kualitas tanah di sebagian besar sawah di Indonesia, disebabkan lebih dari 40 tahun tanah sawah mendapatkan asupan pupuk kimia jumlah besar dan dalam jangka waktu lama, serta kurangnya penggunaan bahan organik dalam sistem produksi padi sawah. Tujuan dari penelitian ini untuk mempelajari pengaruh pemberian pupuk Baranik (Batubara Organik) untuk meningkatan kualitas tanah dan hasil tanaman padi di lahan sawah irigasi. Penelitian ini dilaksanakan pada bulan April sampai Agustus 2014 di lahan sawah irigasi Belitang, Kabupaten OKU timur, menggunakan Rancangan Acak Kelompok Faktorial, dengan 9 kombinasi perlakuan dan diulang 3 kali dengan 10 tanaman contoh. Faktor pertama adalah jenis pupuk dengan 3 taraf yaitu; pupuk kimia anjuran (250 kg urea ha $\left.{ }^{-1}+150 \mathrm{~kg} \mathrm{SP}-36 \mathrm{ha}^{-1}+50 \mathrm{~kg} \mathrm{KCl} \mathrm{ha}^{-1}\right)$, pupuk organik limbah tanaman dosis $5 \mathrm{Mg} \mathrm{ha}^{-1}$ dan pupuk Baranik (Batubara organik) dosis $0,75 \mathrm{Mg} \mathrm{ha}^{-1}$ dan varietas padi dengan 3 taraf yaitu; Mentik Wangi, Gogo Aromatik dan Ciliwung. Aplikasi pupuk Baranik pada 0,75 Mg ha $^{-1}$ telah meningkatkan komponen vegetatif dan hasil padi sekitar 7,17 $\mathrm{Mg} \mathrm{ha}^{-1}$ dibandingkan dengan pupuk organik lainnya, tetapi masih sama dengan dosis yang direkomendasikan pupuk kimia. Di antara varietas, hasil varietas Ciliwung lebih tinggi dari yang lain, yaitu 7,72 $\mathrm{Mg} \mathrm{ha}^{-1}$. Produksi varietas Gogo Aromatik nyata lebih
\end{abstract}


rendah daripada varietas Ciliwung. Pupuk organik Baranik dapat digunakan untuk meningkatkan kesuburan tanah untuk ketahanan pangan.

Kata kunci: Bahan organik, pertanian berkelanjutan, padi, swasembada pangan

\section{INTRODUCTION}

Rice plays an important role in agricultural development in Indonesia because rice is the main staple food in Indonesia. Therefore it is necessary to develop technology that can support food-self sufficiency through sustainable agriculture practices. Pramono (2004) indicated that the quality of most rice fields in Indonesia has been declined due to long term and intensif chemical fertilizer input and lack of organic matter application. The preservation of soil fertility is mainly dependant on the organic matter content of the soil. The use of alternative organic fertilizers needs to be promoted in order to maintain soil fertility and further achieve sustainable agriculture. Hakim et al. (2013) reported that the use of organic fertilizer will reduce the amount of inorganic fertilizers applied on rice field by $50 \%$. Nandakumar et al. (2004) used a lignite-based humic acid to increase nutrient availability in Vertisol and Alfisol of rice fields.

The declined quality of paddy soils is indicated by the decrease of soil organic matter content. Karama et al (1990) showed that about $68 \%$ of a random sample of 30 paddy soils in Indonesia contain $<1.5 \%$ of organic-C and only $9 \%$ of paddy soils contain $>2 \%$ of organic-C. Budianta and Tambas (2004) reported that the quality of soils in the rice productive areas in South Sumatera, especially in Ogan Komering Ulu District has been declined with the average of organic-C content $<1.5 \%$.

The application of organic fertilizer can be an option to improve the quality of agricultural soils and crop yields. Organic fertilizer is in general derived from plant residue and animal manure. Another material that contains high $\mathrm{C}$ and can be used to make organic fertilizer is lignite (soft coal). Lignite contains of C (69\%), H (5.5\%), O (25\%), $\mathrm{N}(0.5 \%), \mathrm{P}_{2} \mathrm{O}(0.04 \%)$, and $\mathrm{K}_{2} \mathrm{O}(36 \%)$. Use of lignite as organic fertilizer can increase the amount of macronutrients $\mathrm{N}, \mathrm{P}, \mathrm{K}, \mathrm{Ca}, \mathrm{Mg}, \mathrm{S}$, and micronutrients $\mathrm{Fe}, \mathrm{Mn}, \mathrm{Cu}, \mathrm{Zn}, \mathrm{Mo}$, and $\mathrm{Cl}$ in soil (Auliarahman 2010). Lignite has long been tried out as a mineral-organic fertilizer that can increase crop growth and yield (Baris and Dincer
1983; Hoffmann and Hoffmann 2007; Sangeetha and Singaram 2007). Haris and Dincer (1983) has used lignite-based fertilizer as a source of nitrogen fertilizer, indicating that lignite is a potential fertilizer. Lignite based fertilizer, of course, contains high amount of humic acids (Garcia et al. 1993), therefore it can be used as a soil amendment as well in order to improve soil organic carbon content.

The drawback of the use of organic fertilizer is that the fertilizer must be applied in a high amount $\left(\mathrm{Mg} \mathrm{ha}^{-1}\right)$ due to the low nutrient content in it. For example, Gofar et al. (2009) reported that the application of organic fertilizer enriched with biofertilizer produced by PT Pupuk Sriwidjaja (Pusri) at $15 \mathrm{Mg} \mathrm{ha}^{-1}$ increased yields of long beans, mustard greens, lettuce, and chili. Further, Sudarsono et al. (2014) showed that the cow manure applied for rice cultivation improved the yield of rice with double row planting space.

Syafrullah (2011) reported that in order to reduce the amount of organic fertilizer applied on the field, the organic fertilizer is previously extracted into humic acids, so that the amount of fertilizer applied can be minimized. In addition, to improve the nutrient content in the organic fertilizer, certain nutrients from natural fertilizer materials and inorganic fertilizers can be added, which further becomes a model of organic plus fertilizer.

The objective of this study is to understand the effect of application of lignite-based organic fertilizer (namely, Baranik fertilizer) on the quality of paddy soil and yield of rice.

\section{MATERIALS AND METHODS}

\section{Study Site and Experimental Design}

The study was conducted in April until August 2014 in a paddy field in Belitang, Ogan Komering Ulu Timur Disctrict, South Sumatera, Indonesia (Figure 1). Soil and fertilizer analyses were conducted in the Laboratory of Soil Chemistry, Biology and Fertility, Faculty of Agriculture, Sriwijaya University. Chemical and physical properties of the soil used in this study are presented in Table 1. 


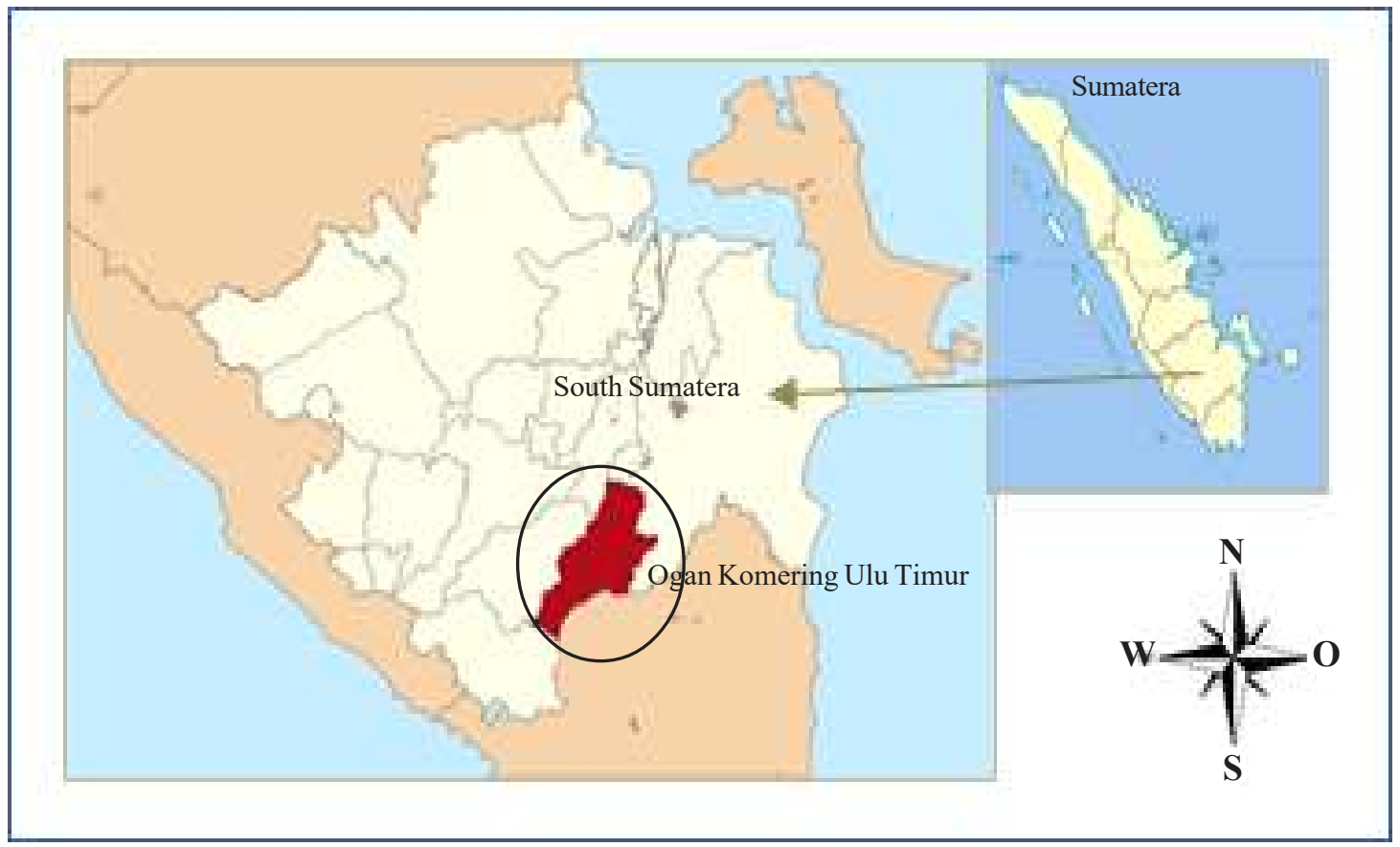

Figure 1. The location of the study.

The study was arranged in a Randomized Block Design with two factors and three replications. The first factor was types of fertilizers applied, consisting of $\mathrm{P}_{0}$ : inorganic fertilizers at recommended dosages $(250 \mathrm{~kg}$ urea $\left.\mathrm{ha}^{-1}+150 \mathrm{~kg} \mathrm{SP}-36 \mathrm{ha}^{-1}+50 \mathrm{~kg} \mathrm{KCl} \mathrm{ha}{ }^{-1}\right) ; \mathrm{P}_{1}$ : organic fertilizer derived from plant residue at 5 $\mathrm{Mg} \mathrm{ha}^{-1}$; and $\mathrm{P}_{2}$ : lignite-based organic fertilizer (Baranik fertilizer) at $750 \mathrm{~kg} \mathrm{ha}^{-1}$. The second factor was rice variety used in the study, consisting of $\mathrm{V}_{1}$ : Mentik Wangi; $\mathrm{V}_{2}$ : Gogo Aromatik; and
$\mathrm{V}_{3}$ : Ciliwung. Chemical properties of Baranik fertilizer are presented in Table 2. Ten rice plants were choosen per plot as samples to determine the vegetative growth and yield.

\section{Rice Planting}

The land was cleared from weeds and plant residue from previous planting. After that, the soil was flooded, ploughed and harrowed until the soil became crumbly. Further, 27 plots were set up in which the size of each plot was $3 \mathrm{~m} \times 2 \mathrm{~m}$. The

Table 1. Initial characteristics of paddy soil in Belitang, Ogan Komering Ulu Timur District.

\begin{tabular}{|c|c|c|c|}
\hline Soil Characteristic & Unit & Value & Criteria \\
\hline $\mathrm{pH}\left(\mathrm{H}_{2} \mathrm{O}\right)$ & - & 4.36 & Slightly acid \\
\hline Total-N & $(\%)$ & 0.20 & Low \\
\hline Organic-C & $(\%)$ & 1.44 & Low \\
\hline Available-P (Bray-1) & $\left(\mathrm{mg} \mathrm{kg}^{-1}\right)$ & 20.5 & High \\
\hline Exchangeable-K & $\left(\right.$ me $\left.100 \mathrm{~g}^{-1}\right)$ & 0.23 & Low \\
\hline $\mathrm{Na}$ & $\%$ & 0.33 & Low \\
\hline $\mathrm{Ca}$ & $\%$ & 0.70 & Very low \\
\hline $\mathrm{Mg}$ & $\%$ & 0.18 & Very low \\
\hline $\mathrm{C} / \mathrm{N}$ ratio & $\%$ & 10.05 & Low \\
\hline \multicolumn{4}{|l|}{ Soil fraction: } \\
\hline Sand & $\%$ & 11.03 & \\
\hline Silt & $\%$ & 40.50 & \\
\hline Clay & $\%$ & 48.05 & \\
\hline
\end{tabular}


Table 2. Characteristics and nutrient content of lignite-based organic fertilizer (Baranik fertilizer).

\begin{tabular}{lccc}
\hline Parameter & Unit & \multicolumn{1}{c}{ Value } & $\begin{array}{c}\text { Standard Quality according to SNI No 70/SR- } \\
140 / 10 / 2011\end{array}$ \\
\hline $\mathrm{pH}$ & - & 7.40 & $4-9$ \\
Water content & $\%$ & 11.07 & $8-20$ \\
Organic-C & $\%$ & 15.08 & Minimum 15 \\
$\mathrm{~N}$ & $\%$ & 14.05 & Minimum 4 \\
$\mathrm{P}$ & $\%$ & 6.71 & Minimum 4 \\
$\mathrm{~K}$ & $\%$ & 5.01 & Minimum 4 \\
$\mathrm{Mg}$ & $\%$ & 1.10 & - \\
$\mathrm{Ca}$ & $\%$ & 3.69 & - \\
$\mathrm{S}$ & $\%$ & 0.09 & - \\
$\mathrm{B}$ & $\mathrm{mg} \mathrm{kg}$ & $250-5000$ \\
$\mathrm{Mo}$ & $\mathrm{mg} \mathrm{kg}^{-1}$ & 0.08 & $2-10$ \\
$\mathrm{Fe}$ & $\mathrm{mg} \mathrm{kg}^{-1}$ & 0.975 & Maximum 500 \\
$\mathrm{Mn}$ & $\mathrm{mg} \mathrm{kg}^{-1}$ & 0.044 & Maximum 5000 \\
$\mathrm{Cu}$ & $\mathrm{mg} \mathrm{kg}^{-1}$ & 0.003 & $250-5000$ \\
$\mathrm{Zn}$ & $\mathrm{mg} \mathrm{kg}^{-1}$ & 0.577 & Maximum 5000 \\
$\mathrm{Co}$ & $\mathrm{mg} \mathrm{kg}^{-1}$ & 0.002 & $5-20$ \\
\hline
\end{tabular}

distance between replicated plots was $1 \mathrm{~m}$, and the space of planting is $30 \mathrm{~cm} \times 30 \mathrm{~cm}$. The rice seeds from each variety (Mentik Wangi, Gogo Aromatik, Ciliwung) have been seeded for 21 days. In $\mathrm{P} 1$ treatment the organic fertilizer derived from plant residue was applied at $5 \mathrm{Mg} \mathrm{ha}^{-1}$ during initial soil tillage, i.e. two weeks before planting. Nitrogen fertilizer was applied two times, i.e. half dosage at 7 days after planting (DAP) and the rest was applied at 42 DAP. Phosphorus and potassium fertilizers were applied at 7 DAP. Irrigation was supplied since the beginning of planting period until $10 \mathrm{DAP}$ at $5 \mathrm{~cm}$ of water height. On the next days, the irrigation was supplied following to the stage of plant growth. Weeding was conducted manually at $15 \mathrm{DAP}$, and the next weeding was conducted if it necessary. Pest and disease control was conducted by applying a home-made organic pesticide. The rice was harvested at 90 DAP.

\section{Observation and Statistical Analysis}

Quality of paddy soil after treatment and parameters of vegetatif growth of rice inlcuding plant height, number of tiller per clump and number of leaf per clump were determined. In addition, parameters of generatif growth of rice, namely number of grain per panicle, dry weight of 1000 grains, dry weight of grains per plot and per ha were determined.

The data of rice growth and yield were statistically analyzed using analysis of variance
(ANOVA). The differences among treatments were tested using Least Significant Difference (LSD) at 5\% level.

\section{RESULTS AND DISCUSSION}

\section{Quality of Paddy Soil after Treatment}

Table 1 showed that the fertility status of the soil before treatment was in general poor in nutrient content, except for available-P. Therefore, it is necessary to improve the soil fertility. An effort that can be choosen to improve soil fertility is by applying fertilizer as indicated by Pramono (2004).

Table 3 indicated that the application organic fertilizer derived from plant residue at $5 \mathrm{Mg} \mathrm{ha}^{-1}$ and Baranik fertilizer at $750 \mathrm{~kg} \mathrm{ha}^{-1}$ on paddy soil can improve several nutrient status of the soil from low to high, especially for organic carbon and available P. In addition, Baranik fertilizer application $\left(\mathrm{P}_{2}\right)$ can improve total $\mathrm{N}$ and $\mathrm{K}$ more than organic fertilizer derived from plant residue (P1). The results showed that the quality of paddy soil has improved after application of Baranik fertilizer, which is indicated by the increase of soil organic-C content from $1.44 \%$ to $2.90 \%$. Although the humic acid content in the Baranik fertilizer was not analyzed, several studies indicates that the humic acid content in lignite is quite high, in which lignite contains various kinds of aromatic groups that are difficult to decompose (Garcia et 
Table 3. Nutrient content of paddy soil in Belitang after fertilization treatments.

\begin{tabular}{ccccc}
\hline \multirow{2}{*}{ Treatments } & \multicolumn{4}{c}{ Nutrient content } \\
\cline { 2 - 5 } & Organic-C $(\%)$ & Total-N (\%) & Available-P $\left(\mathrm{mg} \mathrm{kg}^{-1}\right)$ & Total-K (\%) \\
\hline Initial & 1.44 & 0.20 & 20.5 & \\
$\mathrm{P}_{0}$ & 1.44 & 0.20 & 9 & 0.55 \\
$\mathrm{P}_{1}$ & 3.00 & 0.20 & 24 & 0.65 \\
$\mathrm{P}_{2}$ & 2.90 & 0.44 & 23 & 0.80 \\
\hline
\end{tabular}

al. 1993; Stefanova et al. 1993; Tahir et al. 2011). The humic acids contained in the Baranik fertilizer has resulted in the increase of soil organic matter content. The humic acids are more resistant to soil microorganism activity. The result obtained in the current study is in line with the study of Luttge et al. (2005), which indicated that humic acids in soil can increase soil organic-C content and the humic acids are more resistent to soil microorganism activity, so they can improve soil physical, chemical and biological chararcteristics. Further, Riley et al. (2008) reported that the application of organic fertilizer can improve soil physical characteristics because the organic matter can cement the soil particles or stabilize soil aggregates, so it can help the roots to penetrate the soil deeper. Consequently, the roots can take up more nutrients and water. In addition, organic fertilizer can improve the rhizosphere condition, therefore, it can improve the nutrient cycle and root exudates that further play roles in soil organic matter decomposition and $\mathrm{N}$ mineralization (Morgan et al. 2005).

The improvement of soil physical, chemical and biological characteristics due to the application of Baranik fertilizer is in line with the study of Hsu et al. (2009), which indicated that the application of organic matter can increase soil biological activity and water availability. The increase of water availability in the soil will improve the uptake and transport of nutrients to the plants, as a result the photosynthesis process to produce food supply for plant growth would be assured (Muhakka et al. 2006).

Table 3 showed that the total-N content in the soil did not increase after fertilization, presumably due to the nature of nitrogen that is quickly lost from the soil because it is taken up by plants, leached out or denitrified. This result is consistent with the study of Gusmini et al. (2013), which show that

Table 4. The effects of application of different types of fertilizers and variety of rice on the vegetatif growth of rice.

\begin{tabular}{|c|c|c|c|}
\hline \multirow[b]{2}{*}{ Treatment } & \multicolumn{3}{|c|}{ Parameter of vegetative growth } \\
\hline & Plant height $(\mathrm{cm})$ & $\begin{array}{l}\text { Number of tiller per } \\
\text { clump }\end{array}$ & $\begin{array}{l}\text { Number of leaf per } \\
\text { clump }\end{array}$ \\
\hline \multicolumn{4}{|l|}{ Type of fertilizer } \\
\hline $\begin{array}{l}\text {-P0: Control (recommended doses of } \\
\text { anorganic fertilizers) }\end{array}$ & $106.97 \mathrm{ab}$ & $28.50 \mathrm{ab}$ & $65.83 \mathrm{~b}$ \\
\hline $\begin{array}{l}\text {-P1: Organic fertilizer of plant } \\
\text { residue }\end{array}$ & $102.02 \mathrm{a}$ & $28.36 \mathrm{~b}$ & $65.78 \mathrm{~b}$ \\
\hline $\begin{array}{l}5 \mathrm{Mg} \mathrm{ha}^{-1} \\
\text {-P2: Baranik fertilizer } 0.75 \mathrm{Mg} \mathrm{ha}^{-1}\end{array}$ & $111.92 \mathrm{~b}$ & $2.96 \mathrm{a}$ & $66.05 \mathrm{a}$ \\
\hline Variety of rice: & $103.87 \mathrm{a}$ & $29.67 \mathrm{a}$ & $66.31 \mathrm{a}$ \\
\hline -V1: Mentik Wangi & $99.87 \mathrm{a}$ & $27.59 \mathrm{c}$ & $65.29 \mathrm{c}$ \\
\hline -V2: Gogo Aromatik & $117.18 \mathrm{~b}$ & $30.84 \mathrm{~b}$ & $66.86 \mathrm{~b}$ \\
\hline -V3: Ciliwung & & & \\
\hline
\end{tabular}

Note: The numbers in the same column followed by the same letters are not significantly different according to Least Significant Difference Test at $5 \%$ level. 
Table 5. The effect of application of different types of fertilizers and variety of rice on yield of rice.

\begin{tabular}{|c|c|c|c|c|}
\hline \multirow[b]{2}{*}{ Treatments } & \multicolumn{4}{|c|}{ Yield of rice } \\
\hline & $\begin{array}{c}\text { Number of grains } \\
\text { per panicle }\end{array}$ & $\begin{array}{c}\text { Dry weight of } \\
1,000 \text { grains } \\
\text { (g) }\end{array}$ & $\begin{array}{l}\text { Dry weight of } \\
\text { grains }\end{array}$ & $\begin{array}{l}\text { Dry weight } \\
\text { of grains per } \\
\text { ha }\left(\mathrm{Mg} \mathrm{ha}^{-1}\right)\end{array}$ \\
\hline \multicolumn{5}{|l|}{ Type of fertilizer: } \\
\hline $\begin{array}{l}\text {-P0: Control (recommended doses } \\
\text { of anorganic fertilizers) }\end{array}$ & $141.29 \mathrm{ab}$ & $31.77 \mathrm{ab}$ & $3.30 \mathrm{ab}$ & $5.50 \mathrm{ab}$ \\
\hline $\begin{array}{l}\text {-P1: Organic fertilizer of plant } \\
\text { residue } 5 \mathrm{Mg} \mathrm{ha}^{-1}\end{array}$ & $112.47 \mathrm{a}$ & $29.16 \mathrm{a}$ & $2.65 \mathrm{a}$ & $4.41 \mathrm{a}$ \\
\hline -P2: Baranik fertilizer $750 \mathrm{~kg} \mathrm{ha}^{-1}$ & $172.09 \mathrm{~b}$ & $32.25 b$ & $4.33 \mathrm{~b}$ & $7.17 \mathrm{~b}$ \\
\hline \multicolumn{5}{|l|}{ Variety of rice } \\
\hline -V1: Mentik Wangi & $140.35 \mathrm{ab}$ & $30.75 \mathrm{ab}$ & $3.52 \mathrm{ab}$ & $5.87 \mathrm{ab}$ \\
\hline -V2: Gogo Aromatik & $134.12 \mathrm{a}$ & $29.10 \mathrm{a}$ & $2.68 \mathrm{a}$ & $4.47 \mathrm{a}$ \\
\hline -V3: Ciliwung & $164.37 \mathrm{~b}$ & $32.20 \mathrm{~b}$ & $4.57 \mathrm{~b}$ & $7.62 \mathrm{~b}$ \\
\hline
\end{tabular}

Note: The numbers in the same column followed by the same letters are not significantly different according to Least Significant Difference Test at 5\% level.

$\mathrm{NO}_{3}^{-}$can be leached out from the soil by percolation of water during the cultivation of rice. Furthermore, the amounts of available-P and $\mathrm{K}$ increased due to the application of organic fertilizer from plant residue and Baranik fertilizer.

\section{Vegetative Growth of Rice Plants}

The effects of application of different types of fertilizers and variety of rice on the parameters of vegetatif growth of rice are presented in Table 4.

Table 4 indicated that the plant height and the number of tiller per clump in the plots applied with Baranik fertilizer are significantly higher than those in the plots applied with organic fertilizer from plant residue and recommended inorganic fertilizers. The lowest plant height, number of tiller and number of leaf per clump were measured in the plots applied with organic fertilizer from plant residue. The plant height, number of tiller per clump and number of leaf per clump of variety of Ciliwung are significantly different from other rice varieties.

The number of leaf per clump in the plots applied with Baranik fertilizer is significantly different from that in the plots applied with organic fertilizer from plant residue and inorganic fertilizers at recommended doses (control). However, the number of leaf per clump in the plots applied with organic fertilizer from plant residue and inorganic fertilizers are not significantly different.
Tabel 2 showed that the Baranik fertilizer contains higher organic matter and nutrients than organic fertilizer from plant residue, although the $\mathrm{N}, \mathrm{P}$, and $\mathrm{K}$ contents in the coal-based organic fertilizer are not as high as in the inorganic fertilizers. This result is supported by the fact that the vegetative growth of rice in the plots applied with Baranik fertilizer are better than in other fertilization treatments. The recommended inorganic fertilizers contain high amount of N, P, and $\mathrm{K}$, however, the inorganic fertilizers do not contain other macro and micronutrients that are needed by plants. In contrast, the Baranik fertilizer contains various macro and micronutrients. The organic fertilizer from plant residue contins high organic matter, but the macro and micronutrient content in it is lower than in Baranik fertilizer. As a result, the vegetatif growth of rice applied with Baranik fertilizer is better than that in other fertilization treatments.

The vegetative growth of Ciliwung variety is better than other rice varieties (Mentik Wangi and Gogo Aromatik), due to the Ciliwung variety is the preeminent rice variety, while Mentik Wangi and Gogo Aromatik are included as upland rice varieties that are commonly grown on upland area.

\section{Yield of Rice}

The parameters of generatif growth of rice indicated that the number of grains per panicle, dry weight of 1,000 grains, dry weight of grains 
per plot and dry weight of grains per ha in the plots applied with Baranik fertilizer are significantly different from those in the plots applied with the recommended inorganic fertilizers and organic fertilizer from plant residue. Further, the yield of Ciliwung variety is higher than that of Mentik Wangi and Gogo Aromatik varieties. The results showed that the application of Baranik fertilizer at $750 \mathrm{~kg}$ $\mathrm{ha}^{-1}$ can improve soil fertility or soil quality, which is indicated by the increase of soil organic-C content from $1.44 \%$ to $2.9 \%$. Consequently, the generative growth (yield) of rice in the plots applied with Baranik fertilizer is better than in other fertilization treatments.

The application of Baranik fertilizer resulted in higher yield of rice than the application of inorganic fertilizers and organic fertilizer from plant residue. This phenomenon is due to the fertility status of the soil used in the current study is low, therefore, the application of the recommended inorganic fertilizers is less effective since the initial organic-C content of the soil is low (1.44\%). As a result the capability of the soil to retain nutrients is low as well. In addition, the nutrients contained in the inorganic fertilizers are readily available, in which most of them are probably lost from the soil and only small amounts can be taken up by plants. This phenomenon is in line with the study of Goenadi (2010), which showed that inorganic fertilizers can be lost from the soil through surface runoff $(21 \%)$, volatilization (19\%), fixation by clay minerals (30\%), leaching (13\%), immobilization by soil microorganisms (5\%), consequently only about $12 \%$ of the nutrients can be taken up by plants.

The application of Baranik fertilizer at 750 $\mathrm{kg} \mathrm{ha}^{-1}$ on paddy soil resulted in higher yield of rice than the application of the recommended doses of inorganic fertilizers, due to the inorganic fertilizers release fast available nutrients, which are easily lost through leaching, fixation by clay minerals, immobilization by soil microorganisms, and others. Most of the nutrients in the Baranik fertilizer can be utilized by plants due to the slow release of nutrients from the organic fertilizer. One of the characteristics of organic fertilizer is that the nutrients are slowly available, as a result the rate of plant growth is relatively slow but obvious (Morgan et al. 2005).

Baranik fertilizer is made from humic acid extracts of lignite enriched with a certain nutrients from natural fertilizer and inorganic fertilizer, therefore, the nutrients contained in the Baranik fertilizer is higher than in the organic fertilizer from plant residue. This result corresponds to the study of Pangaribuan et al. (2012), which indicated that the application of bokashi fertilizer or chicken manure combined with half recommended dose of inorganic fertilizer can increase yield of plants and reduce the use of inorganic fertilizer. Further, Widowati (2009) reported that the application of organic fertilizer combined with half recommended dose of inorganic fertilizer can improve growth and yield of vegetable crops.

Besides applying the right type of fertilzer, another factor that determines the increase of plant yield is the variety of plant used. Atman (2007) indicated that variety of plant is an important factor that determines yield of rice. The results showed that the Ciliwung variety used in the current study resulted in higher yield, which is probably due to the Ciliwung variety is the recommended variety for paddy soil, therefore, the yield of Ciliwung variety is better than the upland rice varieties, i.e. Mentik Wangi and Gogo Aromatik. Boutman et al. (2007) reported that upland rice is more tolerant to drought than paddy rice. In short, the environmental factors determine the yield of rice. The optimum plant growth due to the suitability of the rice variety with the location and right fertilization technique will result in an increase of plant height, number of productive tiller, dry weight of 1,000 grains and dry weight of milled grains (Tubur et al. 2012).

To evaluate the results of current study, the yield of Ciliwung variety used in the current study is then compared to its natural yield grown on paddy field with irrigation. The results showed that the yield of Ciliwung variety in the current study is about $7.62 \mathrm{Mg} \mathrm{ha}^{-1}$, while the natural yield of Ciliwung variety is on average $6.5 \mathrm{Mg} \mathrm{ha}^{-1}$, indicating that the yield of Ciliwung variety obtained in the current study is higher than its average yield. The results of current study implied that the application of Baranik fertilizer at $750 \mathrm{~kg} \mathrm{ha}^{-1}$ has successfully improved the yield of rice grown on paddy field.

\section{CONCLUSIONS}

Lignite-based organic fertilizer (Baranik fertilizer) is a potential fertilizer because it can increase the growth and yield of rice. The application of Baranik fertilizer at $750 \mathrm{~kg} \mathrm{ha}^{-1}$ has improved the quality of paddy soil, which is 
indicated by the incrase of organic-C content from $1.44 \%$ to $2.9 \%$ and available-P. In addition, the application of Baranik fertilizer at $750 \mathrm{~kg} \mathrm{ha}^{-1}$ has increased the yield of Ciliwung rice variety up to $7.62 \mathrm{Mg} \mathrm{ha}^{-1}$, while the natural yield of the Ciliwung variety is on average $6.5 \mathrm{Mg} \mathrm{ha}^{-1}$.

\section{ACKNOWLEDGEMENTS}

We would like to thank the students of Department of Agrotechnology, Universitas Muhammadiyah Palembang for helping us on field work, sampling, and laboratory analysis.

\section{REFERENCES}

Atman. 2007. Teknologi budidaya padi sawah Varietas Unggul Baru Batang Piaman. J Ilmiah Tambua VI: 58-64. (in Indonesian).

Auliarahman H. 2010. Pengaruh Sifat Fisik dan Struktur Mineral Batu Bara Lokal Terhadap terhadap Sifat Pembakaran.(http://harizonaauliarahman.blogspot.com/ /batubara.html) accesed on 8 May 2014. (in Indonesian).

Bari ${ }^{\circ} \mathrm{H}$ and S Dinçer. 1983. Lignite-Based Nitrogenous Fertilizers. Energy Sources 7: 87-94. doi: 10.1080/ 00908318308908078

Bouman BAM, E Humphreys, TP Tuong and R Baker. 2007. Rice and water. Adv Agron 92: 187-237.

Budianta D and D Tambas. 2004. Kandungan Logam Berat Cadmium pada Lahan Intensifikasi Pertanian Belitang Oku Timur, Sumatera Selatan. $J$ Pengelolaan Lingkungan dan Sumberdata Alam 2: 45-52. (in Indonesian).

Garcia D, J Cegarra, M Abad and F Fornes. 1993. Effects of the extractants on thecharacteristics of a humic fertilizer obtained from lignite. Bioresource Techn 43:221-225.

Goenadi DH. 2010. Paradigma baru pemupukan untuk terobosan inovatif pertanian. Prosiding Seminar Nasional Teknologi Pemupukan. Balai Penelitian Perkebunan Sembawa. Palembang. 27-28 Juli 2010. pp. 45 -56. (in Indonesian).

Gofar N, Marsi and Sabaruddin. 2009. Teknologi Produksi Mikroba Dekomposer dan Pupuk Hayati Unggul. Fakultas Pertanian Universitas Sriwijaya kerjasama dengan PT. Pupuk Sriwijaya. (in Indonesian).

Gusmini, K Nishimura, Adrinal and T Itani. 2013. Leaching Behaviour of Nitrogen in Forage Rice Cultivation that Applied with Animal Manure. $J$ Trop Soils 18 : 209-216

Hakim N, Agustian and Y Mala. 2012. Application of Organic Fertilizer Tithonia Plus to Control Iron Toxicity and Reduce Commercial Fertilizer Application on New Paddy Field. J Trop Soils 17: 135-142.
Hoffmann K and J Hoffmann. 2007. The Utilization of Peat, Lignite and Industrial Wastes in the Production of Mineral-Organic Fertilizers. Am J Agric Biol Sci 2: 254-259.

HsuYT, TC Shen and SY Hwang. 2009. Soil fertility management and pest responses: A comparison of organic and synthetic fertilization. $J$ Econ Entomol 102: 160-169.

Luttge A, L Zhang and RH Nealson. 2005. Mineral surfaces and their implications for microbial attachment; results from Monte Carlo Simulations and direct surface observations. Am J Sci 305: 766790.

Morgan JAW, GD Bending and PJ White. 2005. Biological costs and benefits to plant-microbe interactions in rhizosphere. $J$ Exp Bot 56: $1729-$ 1739.

Muhakka, D Budianta, Munandar and Abubakar. 2006. Optimalisasi pemberian pupuk organic dan sulfur terhadap pertumbuhan rumput gaja (Pennisetum purpuphoides). J Tanaman Trop 9: 30-41. (in Indonesian).

Nandakumar R, A Saravanan, P Singaram and B Chandrasekaran. 2004. Effect of lignite humic acid on soil nutrient availability at different growth stages of ricegrown on Vertisols and Alfisols. Acta Agron Hung 52: 227-235.

Pangaribuan DH, M Yasir and NK Utami. 2012. Dampak bokhasi kotoran ternak dalam pengurangan pemakaian pupuk anorganik pada budidaya tanaman tomat. J Argonomi Indonesia 40: 204- 210. doi: https://doi.org/10.24831/jai.v40i3.6827. (in Indonesian).

Pramono J. 2004. Kajian penggunaan bahan organik pada padi sawah. Agrosains 6: 11-14. (in Indonesian).

Riley H, R Pommeresche, R Eltun, S Hansen and A Korsaeth. 2008. Soil structure, organic matter and earthworm activity in a comparison of cropping system with contrasting tillage, rotations, fertilizer levels and manure use. Ecosyst Environ 124:275-284.

Sangeetha M and P. Singaram. 2007. Effect of lignite humic acid and inorganic fertilizers on growth and yield of onion. Asian J Soil Sci 2: 108-110.

Sudarsono WA, M Melati and SA Aziz. 2014. Growth and yield of organic rice with cow manure application in the first cropping season. Agrivita 36: 19-35. doi: http://doi.org/10.17503/ agrivita.v36i1.334.

Stefanova M, D Velinova, SP Marinov and R Nikolova. 1993. The composition of lignite humic acids. Fuel 72: 681-684. doi: https://doi.org/10.1016/00162361(93)90581-L.

Syafrullah. 2011. Aplikasi pupuk organik plus pada budidaya SRI (System of Rice Intensification) di pasang surut Sumatera Selatan. J Klorofil 6: 1-6. (in Indonesian). 
Tubur HW, MA Chozin, E Santosa and A Junedi. 2012. Respon agronomi varietas padi terhadap priode kekeringan pada sistem sawah. J Agron Indonesia 40 : 167-173.

Tahir MM, M Khurshid, MZ Khan, MK Abbasi and MH Kazmi. 2011. Lignite derived humic acid effect on growth of wheat plants in different soilss. Pedosphere 21: 124-131
Widowati LR. 2009. Peranan pupuk organik terhadap efisiensi pemupukan dan tingkat kebutuhannya untuk tanaman sayuran pada tanah Inseptisols Ciherang, Bogor. J Trop Soils 14: 221-228. (in Indonesian). 